\title{
Niemieckojęzyczna literatura Szwajcarii bez tabu
}

\author{
[rec. ] Dorota Sośnicka, red., Tabuzonen und Tabubrüche in der \\ Deutschschweizer Literatur, Göttingen: Vandenhoeck \& Ruprecht \\ Verlage, 2020, ss. 384.
}

\section{German-language literature in Switzerland without taboos}

\begin{abstract}
The review article presents and discusses the volume Tabuzonen und Tabubrüche in der Deutschschweizer Literatur published in 2020 by the Vandenhoeck \& Ruprecht publishing house, with the financial support of Jan Michalski Fondation and the University of Szczecin, edited by Dorota Sośnicka, devoted to contemporary phenomena of Swiss literature, literary images of taboo and attempts to break taboos. Short critical references to the texts included in the volume make it possible to identify key issues and the accompanying contexts, and are intended to be a guide to reading the entire, extremely interesting project.
\end{abstract}

Keywords: Contemporary literature, German-language literature in Switzerland, taboo in literature, breaking taboos.

Pytanie o literaturę szwajcarską - $w$ tonie Petera von Matta ${ }^{1}$ - nie brzmi już dzisiaj prowokacyjnie, a miejsce emocji w dyskusji o jej statusie zajęły

1 Peter von Matt jako znawca i wybitny krytyk literacki dystansował się od łatwych ocen literatury szwajcarskiej, to stanowisko tylko nieznacznie złagodził, o czym mówi w wywiadzie: „Germanist Peter von Matt: Wissenschaftliche Qualität ist keine Frage der Nationa- 
argumenty legitymizujące twórczości pisarzy, których pierwszym językiem był i jest Schweizerdeutsch. I choć literaturę Szwajcarii po 1945 roku w skryptach akademickich i popularnych omówieniach nadal przede wszystkim reprezentują „dyżurni” mistrzowie Peter Bichsel, Friedrich Dürrenmatt, Max Frisch, Adolf Muschg, Robert Walser i broniąca parytetu kobiet Gertrud Leutenegger ${ }^{2}$, to literatura ta swą dzisiejszą niezależną i mocną pozycję zawdzięcza twórczości poszukujących i wytrwałych, wrażliwych i empatycznych, zaangażowanych i odważnych pisarek i pisarzy, którzy dzięki krytycznej recepcji ich utworów i wydarzeniom promującym literaturę - jak przyznawana w Solurze nagroda literacka ${ }^{3}$ - coraz lepiej znani są szerokiej grupie czytelników.

Obecność literatury szwajcarskiej w polu literackim obszaru niemieckojęzycznego nadaje mu szczególnej dynamiki i wielowymiarowości. Owa wyjątkowa przestrzeń estetyczna i intelektualna poddawana jest z roku na rok coraz intensywniejszej eksploracji przez własne i międzynarodowe środowisko germanistów. Wiele znaczących monografii, opracowań zbiorowych, a nawet czasopism, skupiających się na twórczości literackiej Szwajcarów pojawiło się na początku lat dziewięćdziesiątych XX wieku4. Także germanistyka polska w istotny sposób przyczynia się do intensywności debaty o (pozornie) najmniej ekspansywnej literaturze pisanej po niemiecku. To między innymi aktywność naukowa ośrodków w Katowicach, Wrocławiu, Poznaniu, Łodzi i last but not least w Szczecinie gwarantuje, że polska germanistyka liczy się w badaniach nad literaturą made in Swiss. Na tym obszarze od wielu lat skupiają się badania prowadzone konsekwentnie i z wielkim zaangażowaniem przez profesor Uniwersytetu Szczecińskiego dr hab. Dorotę Sośnicką, która upowszechnia ich wyniki w licznych publikacjach i animuje

lität", Südkurier, 18 maja 2017, https://www.suedkurier.de/ueberregional/kultur/Germanist-Peter-von-Matt-Wissenschaftliche-Qualitaet-ist-keine-Frage-der-Nationalitaet; art10399,9259654].

2 Ta upraszczająca uwaga ma na celu wywołanie refleksji i rewizję programów kursu historii literatury niemieckojęzycznej, w której często brak miejsca na szersze uwzględnienie literatury szwajcarskiej.

3 Solturner Literaturpreis - to szwajcarska nagroda literacka przyznawana autorom niemieckojęzycznym połączona z festiwalem literackim Soloturner Literaturtage. Autorką nagrodzoną w roku 2020 jest austriacka pisarka Monika Helfer za książkę Die Bagage.

4 Por. m.in. Klaus Pezold i in., red., Geschichte der deutschsprachigen Schweizer Literatur im 20. Jahrhundert (Berlin: Volk und Wissen, 1991); Beatrice von Matt, red., Antworten. Die Literatur der deutschsprachigen Schweiz in den achtziger Jahren (Zürich: NZZ-Verlag, 1991); Rosmarie Zeller, Der Neue Roman in der Schweiz: die Unerzählbarkeit der modernen Welt (Freiburg, Schweiz: Universitätsverlag, 1992). Można w tym dostrzec związek z obchodami 700-lecia powstania Konfederacji Szwajcarskiej, zorganizowanymi w 1991 roku. 
działania służące promocji literatury szwajcarskiej ${ }^{5}$. W to spektrum wpisuje się opublikowana $\mathrm{w}$ renomowanym wydawnictwie Vandenhoeck \& Ruprecht, jako trzeci tom serii współtworzonej przez Monikę Wolting i Pawła Piszczatowskiego „Gesellschaftskritische Literatur - Texte, Autoren und Debatten", monografia zbiorowa Tabuzonen und Tabubrüche in der Deutschschweizer Literatur. Jest ona pokłosiem konferencji naukowej, która odbyła się w Szczecinie 17-19 maja 2018 roku jako kolejne z cyklu spotkanie uznanych helwetologów europejskich i amerykańskich (po wcześniejszych w Madrycie i Salamance - 2005, Wrocławiu - 2007, Bergen - 2011, Glasgow 2014 i w Mariborze - 2016). W międzynarodowym gronie autorów są przedstawiciele dwunastu krajów, eksperci w zakresie literatury szwajcarskiej, zapewniający wysoką jakość dyskusji na podjęty w tomie wielowymiarowy temat, który łączy badania literackie $\mathrm{z}$ badaniami z obszaru nauk społecznych i historycznych.

Problematyka związana z tabu i procesami tabuizacji, implikująca refleksję nad utrwalaniem, naruszeniem i przełamywaniem tabu oraz wynikającymi z tego sankcjami, dotyczy, bez wątpienia, wielu działów humanistyki, ale swą szczególną emanację znajduje w samej literaturze. Zawężenie obserwacji do niemieckojęzycznej literatury szwajcarskiej zapowiada spotkanie $\mathrm{z}$ wyjątkową formacją dyskursywną, ukształtowaną przez wpływy wewnętrzne i zewnętrzne, chronotopiczną i uniwersalną jednocześnie. Spostrzeżenie to dotyczy nie tylko istoty tabu, ale także sposobów jego utrzymywania, oswajania, omijania i przełamywania, a także przywracania i tworzenia nowych tabu we współczesnym świecie oraz strategii związanych z literaryzacją tych zjawisk. To frapujący problem badawczy, który współautorzy zredagowanego przez Dorotę Sośnicką tomu starają się rozwiązać w międzynarodowym wielogłosie, tworząc szczególną harmonię poznania i reflek-

5 Por. m.in. Dorota Sośnicka, Den Rhythmus der Zeit einfangen: Erzählexperimente in der Deutschschweizer Gegenwartsliteratur unter besonderer Berücksichtigung der Werke von Otto F. Walter, Gerold Späth und Zsuzsanna Gahse (Würzburg: Königshausen \& Neumann, 2008); Dorota Sośnicka, Malcolm Pender, red., Ein neuer Aufbruch? 1991-2011. Die Deutschschweizer Literatur nach der 700-Jahr-Feier (Würzburg: Königshausen \& Neumann, 2012); Isabel Hernández i Dorota Sośnicka, red., Fabulierwelten: Zum (Auto)Biographischen in der Literatur der deutschen Schweiz. Festschrift für Beatrice Sandberg zum 75. Geburtstag (Würzburg: Königshausen \& Neumann, 2017); Dorota Sośnicka, „Der «universelle Regionalismus» in der Deutschschweizer Gegenwartsliteratur", w Vielheit und Einheit der Germanistik weltweit, red. Franciszek Grucza, t. 5, Globalisierung - eine kulturelle Herausforderung für die Literaturwissenschaft? Germanistische Abgrenzungen, oprac. Regina Hartmann (Frankfurt am Main: Peter Lang Verlag, 2012), 315-319; Dorota Sośnicka, „Die aktuelle Schweizer Literatur im Spiegel der «Solothurner Literaturtage»", w Helvetische Literaturwelten im 20. Jahrhundert, red. Barbara Rowińska-Januszewska we wsp. z Dorotą Sośnicką (Poznań: Wydawnictwo Rys, 2003), 221-238. 
sji. Szczecińska naukowczyni stworzyła do tego niebanalną ramę, uwzględniając $\mathrm{w}$ strukturze tomu różnorakie formy obecności tabu w przestrzeni publicznej i literackiej. We wprowadzeniu podjęła się udanej próby uporządkowania pojęć i definicji tabu, dzięki czemu czytelnik otrzymuje rzetelną wiedzę i punkt odniesienia do krytycznego oglądu prezentowanych w tomie treści. Cytowana definicja Stephana Rudasa, austriackiego psychiatry i neurologa, zgodnie z którą tabu implikuje „posłuch, bez kwestionowania jego przyczyn"6, wyznacza granice pojęcia tabu i jego realizacji społecznych także w obszarze literatury szwajcarskiej. Sośnicka omawia genezę tabu i wskazuje na przyczyny uwewnętrznienia zakazów przez członków danej wspólnoty, i ich współczesne konteksty. Wchodząc w dyskurs z ważnymi aktualnymi publikacjami z zakresu omawianego zagadnienia, jak Texte und Tabu. Zur Kultur von Verbot und Übertretung von der Spätantike bis zur Gegenwart (2015), czy też Das Lexikon der Tabubrüche (2018)7 , redaktorka tomu podkreśla, że nie samo objęcie jakiegoś obszaru tabu, lecz dopiero wykroczenie przeciw lub złamanie tabu ma znaczenie społeczne poprzez wynikające $\mathrm{z}$ tego sankcje. Przywołując za Schröderem funkcje tabu w życiu społecznym ${ }^{8}$, wyznacza kierunek odczytania, a cytując Hartmuta Krafta ${ }^{9}$, odnosi pojęcie tabu do ponowoczesności, która uzurpuje sobie wolność od wszelkich tabu, i zwraca uwagę na paradoks związany ze swoistą koniunkturą tabu w dobie globalizacji. Wszystkie prezentowane w tomie teksty odnoszą się do literackich obrazów przejawów tabu i jego łamania w konkretnych obszarach kultury i życia społecznego w Szwajcarii.

Bez wątpienia oś problemową tomu wytycza wiodący tekst „Tabubrüche in der deutschschweizerischen Literatur. Exemplarische Beispiele von Hugo Loetscher, Urs Allemann und Jonas Lüscher" autorstwa Petera Rusterholza (Universität Bern), autora wydanej (wraz z Andreasem Solbachem) w wydawnictwie Metzler w 2007 roku najnowszej historii literatury szwajcar-

6 Stephan Rudas, „Stichworte zur Sozialpsychologie der Tabus”, w Tabu und Geschichte. Zur Kultur des kollektiven Erinnerns, red. Peter Bettelheim i Robert Streibel (Wien: Picus, 1994): 19 (w oryginale: „gehorchen, ohne zu fragen”).

7 Alexander Dingeldein i Matthias Emricha, red., Texte und Tabu. Zur Kultur von Verbot und Übertretung von der Spätantike bis zur Gegenwart (Bielefeld: transcript Verlag, 2015); Arne Hoffman, Das Lexikon der Tabubrüche. Grenzüberschreitungen von AfD bis Zoophilie, von „Die letzte Versuchung Christi” bis zu „The Red Pill”, wydanie drugie, rozszerzone i uaktualnione (Erbach: Salax, 2018).

8 Hartmut Schröder, „Zur Kulturspezifik von Tabus. Tabus und Euphemismen in interkulturellen Kontaktsituationen", w Tabu. Interkulturalität und Gender, red. Claudia Benthien i Ortrud Gutjahr (München: Wilhelm Fink Verlag, 2008), 51-70.

9 Hartmut Kraft, Tabu. Magie und soziale Wirklichkeit (Düsseldorf/Zürich: Walter Verlag, 2004). 
skiej $^{10}$. Autor omawia w nim ponownie zjawisko tabu i z tej perspektywy dokonuje oglądu literatury szwajcarskiej, skupiając się na możliwościach tkwiących w samej literaturze, która, by nie stać się schematyczną i odtwórczą, powinna podejmować dialog z różnymi przejawami tabuizacji. Zgodnie z jego tezą zmiana stref tabu w nowoczesnych społeczeństwach jest sejsmografem zmian mentalności tych społeczeństw. Omawiając twórczość Hugona Loetschera, Ursa Allemanna i Jonasa Lüschera, wybitny znawca zwraca uwagę na literacką wartość przełamywania tabu i umożliwiającą ją performatywną funkcję języka. Autor odwołuje się do innych znaczących tekstów szwajcarskich, stwarzając tym samym swoisty punkt odniesienia dla lektury literatury szwajcarskiej.

Rozdział poświęcony literackim strefom tabu i formom ich przełamywania rozpoczyna tekst Anny Fattori (Universit di Roma „Tor Vergata”) zatytułowany „Das enfant terrible Robert Walser. Inhaltliche und formale Tabubrüche in den späten Mikrogramm-Texten“, traktujący o późnej twórczości Roberta Walsera, a konkretnie - skupiony na czterech prozatorskich miniaturach opublikowanych po śmierci mistrza. W swojej interpretacji włoska badaczka ujawnia silny ładunek demaskatorski tych tekstów i analizuje, w jaki sposób - wykorzystując literackie konwencje - pisarz przełamuje tabu moralne, religijne, społeczne i seksualne. Podkreśla przy tym znaczenie struktur, gatunków literackich i środków stylistycznych używanych przez Walsera, dzięki którym pisarz obnażał to, co uchodziło za „zakazane” lub „święte”11. Fattori stwierdza, że pisarz w omawianych mikrogramach polemizuje i prowokuje, łącząc ironię, subwersywność i poetyckość wypowiedzi - i nie jest to w żadnym razie tylko dekonstrukcja. Dojrzały wywód dowodzi kompleksowej znajomości podjętej problematyki. Podobnie tekst Beatrice Sandberg (Universitetet i Bergen) „Tabubrüche und Schuldgefühle. Zu Max Frischs Erzählung Montauk" wyrasta z głębokiego namysłu autorki na temat naruszania i przekraczania tabu, tym razem w twórczości Maxa Frischa. Autobiograficzna powieść Montauk, w której autor wyraźnie przekroczył dopuszczalne granice ujawnienia intymnej sfery swych opisanych tu partnerek, stwarza znakomity pretekst do rozważań natury egzystencjalnej oraz do przypomnienia ówczesnej reakcji środowiska (Peter Bichsel, Uwe Johnson) ${ }^{12}$. Do-

10 Peter Rusterholz i Andreas Solbach, red., Schweizer Literaturgeschichte (Stuttgart: Metzler, 2007).

11 Anna Fattori, „Das enfant terrible Robert Walser. Inhaltliche und formale Tabubrüche in den späten Mikrogramm-Texten", w Tabuzonen und Tabubrüche in der Deutschschweizer Literatur, red. Dorota Sośnicka (Göttingen, Vandenhoeck \& Ruprecht Verlage, 2020), 43.

12 Autorka cytuje m.in. Peter Bichsel, „Bildlegendentexte zu Max Frisch 1911-1991”, DU, z. 12 (1991): 62; Uwe Johnson, Begleitumstände. Frankfurter Vorlesungen (Frankfurt am Main: Suhrkamp, 1980): 451 i nast. 
konując oceny późnej twórczości pisarza, znawczyni twórczości Frischa przywołuje równocześnie debatę nad istotą pisarstwa i przypomina słowa Frischa z wykładów frankfurckich „Nie ma fikcji, która nie polegałaby na doświadczeniu”13 oraz „Tam, gdzie nasze pisanie nie stanie się doświadczeniem samego siebie, nie powstaje literatura, powstają tylko książki"14. Autorowi Stillera poświęciła swoje badania także Isabel Hernández (Universidad Complutense de Madrid). W artykule „«Dass ich Alkoholiker bin, habe ich früher schon gesagt». Über das Trinken als Leitmotiv im Werk von Max Frisch" przełamuje tabu, podejmując temat koincydencji picia i twórczości. Refleksje Hernández nawiązują do wydanego pośmiertnie tekstu Frischa Das Hirn. Eine Notiz ${ }^{15}$, z komentarzami Margit Unser (do 2016 roku kierowniczka Archiwum Frischa w Zurychu). Autor, który nie mógł wyzbyć się lęku przed demencją - utratą funkcji poznawczych i możliwości twórczych, odnajduje ukojenie w alkoholu, co nabiera wagi wobec wybranego na motto artykułu wiersza Charles'a Baudelaire'a ${ }^{16}$. Piciu pisarza towarzyszyła silna autorefleksja, i tak - za Hernandez - picie stało się jednym z motywów przewodnich jego późnej twórczości. Hiszpańska badaczka twórczości Frischa dostrzega w alkoholu nie tylko rodzaj „symbolicznej śmierci”, ale wskazuje go także jako przyczynę realnego umierania artysty poprzez utratę pamięci krótkotrwałej. To pamiętniki stały się więc ostatecznie szczerym, nieupiększonym dokumentem jego życia, paradoksalnie jednak to te właśnie pamiętniki przekraczają ramy gatunku i ukazują znakomicie miejsce przecinania się literatury i sztuki, rzeczywistości i fikcji. To w pamiętnikach, jak podkreśla Hernandez, ukryte są klucze do odczytania twórczości, która dzięki intensywności wewnętrznego głosu pisarza przełamuje niejedno społeczne tabu.

W tej samej grupie tekstów znalazło się omówienie niepublikowanej powieści Hermanna Burgera Lokalbericht pióra Petera Utza (Université de Lausanne). W artykule „In Tabuzonen der helvetischen Wirklichkeit. Hermann Burgers unpublizierter Roman Lokalbericht" autor unaocznia, jak wiele tabu funkcjonujących $\mathrm{w}$ społeczeństwie małego miasteczka powieść ujawnia i przekracza. Peter Utz, m.in. redaktor serii wydawniczej „Schweizer Texte” ukazującej się od 1993 roku i obejmującej ponad 50 tytułów, odsłania też

13 Max Frisch, Schwarzes Quadrat. Zwei Poetikvorlesungen, red. Daniel de Vin (Frankfurt am Main: Suhrkamp, 2008), 30.

14 Max Frisch, Schwarzes Quadrat, 30.

15 Max Frisch, „Das Hirn. Eine Notiz. Mit einer Vorbemerkung von Margit Unser”, Sinn und Form 68, nr 3 (2016): 415.

16 Charles Baudelaire: „Man muß immer trunken sein. Das ist alles: die einzige Lösung. Um nicht das furchtbare Joch der Zeit zu fühlen, das euere Schultern zerbricht und euch zur Erde beugt, müsset ihr euch berauschen, zügellos. Doch womit? Mit Wein, mit Poesie oder mit Tugend, womit ihr wollt. Aber berauschet euch". 
kulisy egzystencji i twórczości przedwcześnie zmarłego pisarza. W jego ocenie już ten powieściowy debiut sprzed pięćdziesięciu lat zdradzał twórczy i krytyczny zmysł Burgera i pozwolił dostrzec w nim możliwego następcę najlepszych tradycji literatury szwajcarskiej (w nawiązaniu do nowel z tomu Die Leute von Seldwylla Gottfrieda Kellera).

Kolejnym przykładem omówienia manifestacji tabu i przerwania tabu w twórczości literackiej są refleksje Dominika Müllera (Université de Genève) nad literackimi implikacjami gwary szwajcarskiej w rozdziale: „Die Geschichte der Deutschschweizer Mundartliteratur als eine Geschichte von Tabubrüchen? C.A. Loosli, Kurt Marti, Martin Frank". Wiodący szwajcarski germanista, prezydent fundacji Schweizerische Schillerstiftung przyznającej najbardziej renomowaną nagrodę literacką w Szwajcarii, który był m.in. redaktorem dwóch z siedmiu tomów dzieł zebranych Gottfrieda Kellera ${ }^{17}$ oraz członkiem zespołu, który w 32 tomach przygotował ich wydanie historyczno-krytyczne ${ }^{18}$, dostrzega ograniczenia wynikające z posługiwania się ,Schweizerdeutsch' tylko przez samych Szwajcarów, co upośledza recepcję literatury powstającej w gwarze, i zastanawia się nad jej status quo. Za Dieterem Fringelim, autorem rozdziału poświęconego szwajcarskiej literaturze gwarowej w tomie Die deutschsprachige Schweizer Literatur des 20. Jahrhunderts ${ }^{19}$, Müller dostrzega w gwarowości z jednej strony tabu, z drugiej zaś dumną oczywistość („Mundart in der Schweiz: Tabu seit alters her, stolze Selbstverständlichkeit?") ${ }^{20}$. Za tych, którzy przełamują tabu, uważa pisarzy poszukujących w literaturze pisanej gwarą nowych form ekspresji, i wskazuje na rolę, jaką w swoistej reinterpretacji i rekonstrukcji literatury gwarowej odgrywają C.A. Loosli, Martin Frank i Pedro Lenz, uprawiający literaturę popularną. Wskazuje przy tym na istotną rolę Das Kleine Lexikon der Provinzliteratur (Zürich 2005) Pedro Lenza w rozpoznaniu tego fenomenu ze względu na ironiczny i autoironiczny charakter tekstu. Müller zwraca uwagę na obecność na scenie literatury gwarowej także tych autorów, którzy odnoszą sukcesy, pisząc w standardowym niemieckim. Zdaniem autora literatura gwarowa rozwija się dzięki przełamywaniu tabu (badacz wykluczył z pola obserwacji teksty noszące znamiona literatury popularnej). Twórczość samego Kurta Martiego znajduje się w centrum uwagi polskiego germanisty Roberta Rducha, który dowodzi dwoistości postawy pisarza i pastora wobec

17 Gottfried Keller, Sämtliche Werke in sieben Bänden. Bibliothek Deutscher Klassiker (Frankfurt am Main: Suhrkamp, 1989-1995).

18 Gottfried Keller, Sämtliche Werke. Historisch-kritische Ausgabe, red. Walter Morgenthaler, Ursula Amrein, Thomas Binder i in. (Basel/ Frankfurt am Main, Zürich: Stroemfeld Verlag/ Verlag Neue Zürcher Zeitung, 1992-2012).

19 Pezold i in., Geschichte der deutschsprachigen Schweizer Literatur.

20 Pezold i in., Geschichte der deutschsprachigen Schweizer Literatur. 
tabu, ukazując go zarówno jako przełamującego, jak i tego, który stoi na straży tabu: „Tabubrecher und Tabuschützer Kurt Marti. Phänomenologie des helvetischen Beschweigens nach 1945“. Rduch analizuje oryginalną koncepcję tabu w ujęciu Martiego, ujawniając jej sprzeczności, i przytacza różne podejścia do tabu w twórczości szwajcarskiego pisarza i publicysty, a równocześnie teologa i pastora. Ukazuje głęboki namysł Kurta Martiego nad człowieczeństwem i przyszłością cywilizacji, legitymując swe twierdzenia celnymi spostrzeżeniami o naturze literatury. Tekst stanowi też interesujący portret pisarza, pragnącego lepszego świata opartego na tolerancji i świadomości ekologicznej.

Drugi rozdział monografii poświęcony jest problematyce tabu w kontekście historyczno-politycznym („Geschichtlich-politische Tabubrüche und Tabuzonen”), a rozpoczyna go błyskotliwy tekst Malcolma Pendera (Strathclyde University Glasgow) „Geschichten als Tabubrüche. Walter Matthias Diggelmann (1927-1979) und sein Roman Die Hinterlassenschaft". Pender odniósł swoją analizę tej dokumentalnej, społeczno-krytycznej powieści do całej działalności Diggelmanna w przestrzeni publicznej, począwszy od lat 60. XX wieku, a w szczególności do artykułu „Schweizer Tabus, Schweizer Sünden" z 1974 roku$^{21}$, w którym pisarz i publicysta w przewrotny sposób rozlicza swoją ojczyznę z pielęgnowania mitu własnej szczęśliwej przeszłości, co prowadziło do tabuizacji tego, co niewygodne. Autor artykułu sarkastycznie stwierdza, powołując się na stanowiska pisarzy i publicystów, że przełamywanie tabu dotyczącego okresu drugiej wojny światowej to praca syzyfowa, a jednym z tych niepokornych, którzy w sztafecie pokoleń pchali kamień prawdy w górę, był właśnie zmarły przed czterdziestu laty Diggelmann. Podobny ogląd szwajcarskiej rzeczywistości w twórczości Ottona F. Waltera (1928-1994) zdecydował o kształcie artykułu Corinny Jäger-Trees (Schweizerisches Literaturarchiv, Bern): „«Alles [...] müsste notiert, müsste schreibend eingeholt und so der Befragung zugänglich gemacht werden». Tabuzonen und -brüche in Otto F. Walters Zeit des Fasans". Autorka przekonuje o konieczności świadomego używania pojęcia tabu, ukazując rozdźwięk między klasycznym wywodem Zygmunta Freuda, przedstawionym w Totem i tabu22, i współczesnym nadużywaniem słowa tabu w publicystyce, co przyczynia się do jego sprzeniewierzenia i dewaluacji. Rewizja aktualnych publikacji na temat tabu skłoniła Jäger-Trees do

21 Walter Matthias Diggelmann, „Schweizer Tabus, Schweizer Sünden (1974)”, w Walter Matthias Diggelmann, Feststellungen. Ein Lesebuch. Texte 1963 bis 1978 (Zürich: Rotpunkt, 1978), 115-119.

22 Sigmund Freud, Totem und Tabu. Einige Übereinstimmungen im Seelenleben der Wilden und der Neurotiker (Leipzig: Internationaler Psychoanalytischer Verlag, 1922). 
śmiałych konstatacji na temat negatywnych społecznie skutków tabuizowania przeszłości, albowiem tylko rozliczenie z przeszłością może uwolnić potencjał społeczeństwa do autorefleksji, a ta doprowadzić do zmiany. Taki wniosek płynie też z jej odczytania powieści Ottona W. Waltera Zeit des Fasans, uznawanej za opus magnum pisarza. Badaczka odnosi się do przełomowej roli powieści dla zbiorowej egzegezy Szwajcarów, ukazując, jak tabu przenika przestrzeń publiczną i prywatną ( $\mathrm{w}$ tym - w odniesieniu do samego pisarza).

Tematem kolejnego artykułu „Verdingkinder - sozialer und nationaler Kontext eines anhaltenden Tabus" jest wciąż obecne w przestrzeni kulturowej współczesnej Szwajcarii społeczne i narodowe tabu - los dzieci oddawanych na służbę. Autor tego rzeczowego przedstawienia - Dariusz Komorowski (Uniwersytet Wrocławski) - ze znawstwem i wrażliwością podejmuje temat dzieci pracujących przymusowo w chłopskich rodzinach adopcyjnych w Szwajcarii i omawia literacką reprezentację tej społecznie sankcjonowanej praktyki. Życie i praca „dzieci kontraktowych” na wsi nie wpisuje się w obraz „Szwajcarskiego imaginarium społecznego" 23 i podważa pielęgnowane i ugruntowane postrzeganie ludzi pracujących na wsi jako czysty i mocny fundament społeczeństwa. W podobnym społeczno-krytycznym tonie utrzymany jest tekst Joanny Jabłkowskiej (Uniwersytet Łódzki) odzierający z iluzji bezinteresownego humanizmu pomoc krajom rozwijającym się: „Entwicklungshilfe als getarnter Kolonialismus. Hundert Tage von Lukas Bärfuss". Autorka dostrzega w zaangażowanym społecznie pisarstwie Lukasa Bärfussa (ur. 1971) programowe podważanie utartych poglądów i prowokacyjne przełamywanie społecznych tabu, co zapowiada już jego pierwsza powieść. Dzięki wielopłaszczyznowej analizie Jabłkowska dokonuje kontekstualizacji tekstu Bärfussa, prowadzącej do jej symbolicznego odczytania. Według polskiej znawczyni niemieckojęzycznej literatury współczesnej (nie)zamierzone porównanie przez pisarza ludobójstwa w Ruandzie ze zbrodnią Holokaustu „instrumentalizuje” wprawdzie cierpienie ludzi w Afryce, ale jest jednocześnie aktem odwagi przez przywołanie kwestii (nie)winnej Szwajcarii i poddanie jej publicznej dyskusji.

Trzeci kompleks tematyczny stanowią artykuły zwracające się ku problematyce tabu wynikającego ze stosunku do kwestii płciowych i seksualnych („Geschlechtsspezifische und sexuelle Tabuzonen”). Pierwsza głos zabiera Barbara Pogonowska (Uniwersytet Śląski w Katowicach), która poddaje analizie opowiadanie Annemarie Schwarzenbach (1908-1942) Eine Frau zu sehen ${ }^{24}$.

23 Autor wielokrotnie odwołuje się do pojęcia „soziales Imgaginarium”, 165, 166, 170.

24 Walter Fähnders i Sabine Rohlf, red., Annemarie Schwarzenbach. Analysen und Erstdrucke. Mit einer Schwarzenbach-Bibliographie (Bielefeld: Aisthesis, 2005). 
Podejmując temat miłości homoerotycznej w późniejszych teksach pisarki i podróżniczki, związanej intymnie z Eriką Mann, badaczka wkracza na trudny teren, obwarowany mimo znacznej liberalizacji licznymi tabu. W erudycyjny sposób wskazuje wczesne literackie tradycje opisu (Gilgamesz) i późniejsze mechanizmy tabuizowania miłości homoseksulanej. Schwarzenbach w swych powieściach Pariser Novelle II (1928), Freunde um Bernhard (1931), Flucht nach oben (1933) i Tod in Persien (1935/1936) stosuje strategie ukrycia prawdziwej natury opisywanych związków z uwagi na mechanizmy wykluczenia funkcjonujące w społeczeństwie. 0 mechanizmach wypierania homoseksualizmu z debaty publicznej pisze także słowacki badacz Ján Jambor w artykule: „Homosexualität als tabuisierte Verhaltensweise der bürgerlichen Gesellschaft in Alain Claude Sulzers Ein perfekter Kellner". Nagrodzona i przetłumaczona na dziesięć języków debiutancka powieść urodzonego w 1953 roku Sulzera zagląda za mieszczańską fasadę szwajcarskiego dobrostanu i ukazuje skomplikowaną naturę ludzką w poszukiwaniu tożsamości. Natomiast Karin Baumgartner (University of Utah) w artykule „Geschichte(n) und Geschlecht in den Romanen der Schweizer Autorin Eveline Hasler" podejmuje zainicjowane przez krytykę feministyczną i podjęte przez studia genderowe zadanie przywracania pamięci kobietom, których faktyczna rola $w$ historii przez wiele lat nie była dostrzegana ze względu na płeć i patriarchalną strukturę społeczną. Powieści Anna Göldin. Letzte Hexe (1982) i Die Wachsflügelfrau (1991) oraz kolejne książki przypominające zapomniane sylwetki kobiet zapewniły Eveline Hasler sukces czytelniczy i rozpoznawalne miejsce w literaturze współczesnej, jednak - jak zastrzega Baumgartner - jej dzieło nie zostało dokończone, a niekiedy wydaje się sprzeniewierzone przez komercyjne zabiegi marketingowe służące gminom związanym z bohaterkami opisanych historii, jak na przykład Anna Goldi ${ }^{25}$.

O tabu w sferze obyczajowej i religijnej („Religiöse und sittliche Tabuzonen") traktują trzy kolejne artykuły, z których każdy eksponuje inne nieobecne i niepożądane treści i zachowania. Daniel Annen (Kantonschule Kollegium Schwyz) zwraca się ku twórczości Thomasa Hürlimanna w rozdziale: „Löcher in der gesellschaftlichen Hochglanzfolie. Tabubruch bei Thomas Hürlimann“. Jego przenikliwa ocena sfer tabu obecnych w społecznym postrzeganiu religii, życia, śmierci i cielesności każe zastanowić się nad kondycją współczesnych społeczeństw. Autor pokazuje, jak Hürlimann dekonstruuje utarte schematy myślenia o Bogu i dopiero przełamując tabu mające Boga chronić, lepiej służy sprawie wiary. W bardzo rozważnym tekście Vesny Kondrič Horvat (Univerza v Mariboru) „«Ich begann eine Buchhaltung

25 Autorka wskazuje na konkretne działania np. Anna Göldi Museum w gminach Ennenda i Hänggiturm. 
meines Lebens zu erstellen». Zu einem Tabuthema im Roman Koala von Lukas Bärfuss" przedstawiony został jeden z tematów często wypieranych w społeczeństwach zorientowanych na sukces - samobójstwo. Reprezentująca słoweńską germanistykę badaczka z wrażliwością eksploruje bardzo osobistą powieść niepokornego i stale podejmującego trudne kwestie społeczne pisarza, ukazując mechanizmy tabuizacji i sankcje związane $\mathrm{z}$ łamaniem tabu, łącząc temat ochrony wymierających gatunków z brakiem zrozumienia dla problemów egzystencjalnych ludzi.

$\mathrm{Na}$ szczególną uwagę zasługują rozważania Gonçalo Vilas-Boasa (Universidade do Porto), gdyż autor jako jedyny porusza problematykę tabu w społeczności żydowskiej. Jego artykuł „Wie man jüdisch-orthodoxe Traditionen hinter sich lässt. Thomas Meyers Roman «Wolkenbruchs wunderliche Reise in die Arme einer Schickse»" wprowadza czytelnika do świata żydowskich tradycji i pozwala doświadczyć bogactwa i kolorytu obowiązujących w nim zasad i zwyczajów. Autor podkreśla, że Meyer wskazał w swej powieści także opresyjną stronę życia we wspólnocie, która kontroluje indywidualne próby wyłamania się z reguł jej świata. Również w warstwie językowej powieść jest przykładem autonomicznego podejścia pisarza do tematu26.

Po serii artykułów stanowiących jednostkowe analizy powieści, rozdział kończy przeglądowa rozprawa o sposobach tabuizacji „szczęścia”. Margrit V. Zinggeler (Eastern Michigan University) w artykule „Tabuisierung und Tabubruch von «Glück» in der Deutschschweizer Literatur" stawia tezę, zgodnie z którą w niemieckojęzycznej literaturze Szwajcarii - zwłaszcza po II wojnie światowej i w literaturze najnowszej - „szczęście” jest tematem tabu, w przeciwieństwie do literatury amerykańskiej analogicznego okresu, i udowadnia ją na wybranych przykładach. Autorka stawia pod rozwagę fakt, że Szwajcaria jako jeden z najszczęśliwszych krajów na świecie paradoksalnie w literaturze unika tematów związanych ze szczęściem, takich jak dążenie do szczęścia czy happy end.

O obszarach tabu w zakresie sztuki i cywilizacji („Künstlerisch-zivilisatorische Tabuzonen") piszą w omawianym tomie Jürgen Barkhoff (Trinity College Dublin, University of Dublin), Ewa Mazurkiewicz (Uniwersytet Śląski w Katowicach), Daniel Rothenbühler (Hochschule der Künste Bern) i Dorota Sośnicka (Uniwersytet Szczeciński). Barkhoff w przekonującym wywodzie „Pygmalion auf der Alp. Hansjörg Schneiders Sennentuntschi als Theaterskandal und Tabubruch", odwołując się do dzisiejszej popularności i medialnego sukcesu pisarza, analizie poddaje jego dramat z początków kariery (1972) i umieszcza go w kontekście ruchu emancypacyjnego w Szwajcarii,

26 Koloryt nadają tekstowi słowa w jiddisch, takie jak 'nostichl' na chusteczkę do nosa, 'sininke' na synka, czy ‘schikse' na kobiety nie-Żydówki. 
która jako ostatni kraj europejski (poza Lichtensteinem) przyznała kobietom prawa wyborcze w 1971 roku. Autor ze znawstwem problematyki podejmuje się wyjaśnienia tła społeczno-politycznego tej późnej decyzji i w kapitalnym wywodzie ukazuje trafność wczesnego tekstu Schneidera, który zachwycił samego Friedricha Dürrenmatta.

Teatrowi, który czerpie z życia i znany jest z bezpardonowego opisu zastanej rzeczywistości, czego instrumentem jest łamanie tabu, poświęciła swoje poszukiwania naukowe Ewa Mazurkiewicz w rozdziale: „«Wir reden viel, wir lachen viel, und ab und zu gibt es eine Kreuzigung». Milo Raus Theater zwischen Provokation und Engagement". W swoim tekście przedstawia wybrane projekty reżysera i twórcy teatralnego o międzynarodowej sławie Milo Raua, twórcy IIPM - International Institute of Political Murder z siedzibą w Szwajcarii i Niemczech. W twórczości autora, który ma na swoim koncie ponad pięćdziesiąt inscenizacji, Mazurkiewicz dostrzega postawę nieprzejednanego obrońcy prawdy o wyjątkowym słuchu społecznym, piętnującego bezpardonowo wszelkie przejawy fałszu. Kreśląc sylwetkę twórcy jako łamacza tabu i przytaczając jego poglądy na temat roli teatru, odnosi się do wypowiedzi Raua, który określa swoją działalność jako „archeologię” naszych czasów ${ }^{27}$. Jego stanowisko Mazurkiewicz plasuje między zaangażowaniem a prowokacją.

W tekście poświęconym Walterowi Vogtowi autor nie tylko przypomina sylwetkę i twórczość nadzwyczaj produktywnego autora (i aktywnego zawodowo lekarza), którego wydana dotąd spuścizna to dziesięć obszernych tomów obejmujących teksty prozą, utwory dramatyczne, słuchowiska i wiersze, lecz także wskazuje na wspólny mianownik wielu utworów (w tomach Maskenzwang, Vogel auf dem Tisch i w powieściach autobiograficznych) - przełamywanie tabu językowego wszędzie tam, gdzie standardowy język zawodzi wobec nowych zjawisk.

Apokaliptyczne wizje, język dążący do sprostania kompleksowości świata jako wyraz głębokiego namysłu nad przyszłością planety i żyjących na niej ludzi - te tematy odnajduje i rozważa Dorota Sośnicka (Uniwersytet Szczeciński) w prozie Reto Hänny'ego. W artykule „Entführung in «verdrängte Tabu-Zonen unserer Zivilisation». Zu Reto Hännys «Bilderbuch» "Helldunkel»" wchodzi w dwugłos z pisarzem, ujawniając czytelnikowi wyjątkowość jego prozy i uzasadniając, dlaczego utwór Helldunkel. Ein Bilderbuch, który w 1994 roku uzyskał literacką nagrodę im. Ingeborg Bachmann i był entuzjastycznie przyjęty przez krytykę literacką, nagle stał się niewygodny i wywołał liczne kontrowersje, prowadzące wręcz do pogróżek kierowanych

27 Milo Rau, „Muscionico, Daniele/Scheu, Rene: Politische Kunst ist auf links gedrehtes Wutbürgertum", Interview, w Neue Zürcher Zeitung (12.01.2017). 
pod adresem autora i w efekcie do jego kryzysu twórczego. Jak wykazuje Sośnicka, stało się tak za sprawą niepokornej postawy pisarza, dążącego do „oświetlania” i wydobywania z mroku niewygodnych społecznie treści, ale także wskutek nieuzasadnionego interpretowania wybranych elementów utworu przez niektórych krytyków literackich na bazie własnych wyobrażeń i zakorzenionych uprzedzeń.

Przedostatni takt monografii przypomina rozmowę redaktorki tomu $\mathrm{z}$ Reto Hännym nawiązującą do wieczoru autorskiego $\mathrm{w}$ Szczecinie 18.05.2018 r., kiedy czytał m.in. fragmenty ze swojej książki Am Boden des Kopfes. Verwirrungen eines Mitteleuropäers in Mitteleuropa. Opisuje w niej podróż do Polski w październiku 1989 roku i spotkania na uniwersytetach we Wrocławiu, Krakowie, Toruniu, Warszawie i Lublinie. Rozmowa jest okazją uporządkowania wrażeń i emocji związanych z tą podróżą, ale przypomina także kontrowersje wokół utworu Helldunkel oraz jej skutki dla pisarza i jego dalszej twórczości. Takt ostatni tomu stanowi fragment prozy Reto Hänny'ego EINBRUCH DER MUSIK na podstawie nieopublikowanego wówczas i później zmienionego manuskryptu ${ }^{28}$. Tekst stanowi swoisty kontrapunkt dla dyskusji podejmowanych przez naukowców podczas szczecińskiej konferencji, udowadniając, że pierwsze i ostatnie słowo należy do pisarza.

Stwierdzenie, że omawiana monografia stanowi bardzo ważny głos w dyskusji nad miejscem literatury szwajcarskiej pisanej po niemiecku, ma niepodważalne uzasadnienie w zamieszczonych tu tekstach, podporządkowanych przemyślanej koncepcji tomu. Pierwszym zwiastunem jego unikalności jest umieszczona na okładce grafika Friedricha Dürrenmatta Herkules: Kopf an Kopf mit Mamut [Herkules: Czołowe starcie z mamutem] ${ }^{29}$. To nie przypadkowy zbiór naukowych wypowiedzi, lecz kompletna i wielopłaszczyznowa narracja na temat obszarów wykluczonych z powszechnej dyskusji za przekraczanie przez nie sankcji społecznych, i w końcu jest to wypowiedź na temat literatury, która wobec fenomenu licznych tabu dyscyplinujących kolektywny obraz (niemieckojęzycznej) Szwajcarii zachowuje swą twórczą autonomię, balansując między strategiami konstrukcji i dekonstrukcji tabu i ukazując estetyczne i moralne skutki zniewolenia jednostek i społeczeństw przez zakazy, kary i rozliczne formy wykluczenia. Już z tego względu publikacja pod redakcją Doroty Sośnickiej zasługuje na lekturę i upowszechnienie jako cenny tekst źródłowy na studiach germanistycznych, dla helwetologów jest zaś pozycją obowiązkową.

28 Opublikowany w tomie fragment pochodzi z najnowszej książki pisarza: Reto Hänny, Sturz. Das dritte Buch vom Flug (Berlin: Matthes \& Seitz, 2020).

29 Friedrich Dürrenmatt, Herkules, Kopf an Kopf mit Mammut. Sammlung Centre Dürrenmatt Neuchâtel (C) CDN/ Schweizerische Eidgenossenschaft. 


\section{References}

Acker, Robert, and Marianne Burkhard. Blick auf die Schweiz. Zur Frage der Eigenständigkeit der Schweizer Literatur seit 1970. Amsterdam: Rodopi, 1987.

Bichsel, Peter. "Bildlegendentexte zu Max Frisch 1911-1991." DU, no. 12 (1991): 62.

Burns, Barbara, and Malcolm Pender, eds. Konstruktionen der Vergangenheit in der Deutschschweizer Literatur. Würzburg: Königshausen \& Neumann, 2015.

Diggelmann, Walter Matthias. "Schweizer Tabus, Schweizer Sünden (1974).” In Walter Matthias Diggelmann. Feststellungen. Ein Lesebuch. Texte 1963 bis 1978, 115-119. Zürich: Rotpunkt, 1978.

Dingeldein, Alexander, and Matthias Emrich, eds. Texte und Tabu. Zur Kultur von Verbot und Übertretung von der Spätantike bis zur Gegenwart. Bielefeld: transcript Verlag, 2015.

Fähnders, Walter, and Sabine Rohlf, eds. Annemarie Schwarzenbach. Analysen und Erstdrucke. Mit einer Schwarzenbach-Bibliographie. Bielefeld: Aisthesis, 2005.

Freud, Sigmund. Totem und Tabu. Einige Übereinstimmungen im Seelenleben der Wilden und der Neurotiker. Leipzig: Internationaler Psychoanalytischer Verlag, 1922.

Frisch, Max. "Das Hirn. Eine Notiz. Mit einer Vorbemerkung von Margit Unser." Sinn und Form 68, no. 3 (2016): 415-417.

Frisch, Max. Schwarzes Quadrat. Zwei Poetikvorlesungen, edited by Daniel de Vin. Frankfurt am Main: Suhrkamp, 2008.

Hoffman, Arne. Das Lexikon der Tabubrüche. Grenzüberschreitungen von AfD bis Zoophilie, von "Die letzte Versuchung Christi" bis zu "The Red Pill", revised second edition. Erbach: Salax, 2018.

Johnson, Uwe. Begleitumstände. Frankfurter Vorlesungen. Frankfurt am Main: Suhrkamp, 1980.

Kraft, Hartmut. Tabu. Magie und soziale Wirklichkeit. Düsseldorf/Zürich: Walter Verlag, 2004.

Matt von, Beatrice, ed. Antworten. Die Literatur der deutschsprachigen Schweiz in den achtziger Jahren. NZZ-Verlag, Zürich 1991.

Matt von, Peter. "Germanist Peter von Matt: 'Wissenschaftliche Qualität ist keine Frage der Nationalität."' Accessed November 16, 2020. https://www.suedkurier.de/ueberregional/kultur/Germanist-Petervon-Matt-Wissenschaftliche-Qualitaet-ist-keine-Frage-der-Nationalitaet;art10399,9259654. 
Pezold, Klaus, Michael Böhler, Dieter Fringeli, Christa Grimm, Manfred Gsteiger, Armin Gerd Kuckhoff, Birgit Lönne, Klaus Dieter Schult, Wladimir Sedelnik, and Ilona Siegel, eds. Geschichte der deutschsprachigen Schweizer Literatur im 20. Jahrhundert. Berlin: Volk und Wissen, 1991.

Rau, Milo. "Muscionico, Daniele/Scheu, Rene: Politische Kunst ist auf links gedrehtes Wutbürgertum". Interview. Neue Zürcher Zeitung (12.01. 2017).

Rudas, Stephan. "Stichworte zur Sozialpsychologie der Tabus." In Tabu und Geschichte. Zur Kultur des kollektiven Erinnerns, edited by Peter Bettelheima, and Robert Streibel, 17-20. Wien: Picus, 1994.

Rusterholz, Peter, and Andreas Solbach, eds. Schweizer Literaturgeschichte. Stuttgart: Metzler, 2007.

Schröder, Hartmut. "Zur Kulturspezifik von Tabus. Tabus und Euphemismen in interkulturellen Kontaktsituationen." In Tabu. Interkulturalität und Gender, edited by Claudia Benthien, and Ortrud Gutjahr, 51-70. München: Wilhelm Fink Verlag, 2008.

Sośnicka, Dorota, and Malcolm Pender, eds. Ein neuer Aufbruch? 1991-2011. Die Deutschschweizer Literatur nach der 700-Jahr-Feier. Würzburg: Königshausen \& Neumann, 2012.

Sośnicka, Dorota. “Der ,universelle Regionalismus' in der Deutschschweizer Gegenwartsliteratur." In Vielheit und Einheit der Germanistik weltweit, edited by Franciszek Grucza, vol. 5: Globalisierung - eine kulturelle Herausforderung für die Literaturwissenschaft? Germanistische Abgrenzungen, edited by Regina Hartmann, 315-319. Frankfurt am Main: Peter Lang Verlag, 2012.

Sośnicka, Dorota. “Die aktuelle Schweizer Literatur im Spiegel der „Solothurner Literaturtage." In Helvetische Literaturwelten im 20. Jahrhundert, edited by Barbara Rowińska-Januszewska with Dorota Sośnicka, 221-238. Poznań: Wydawnictwo Rys, 2003.

Sośnicka, Dorota. Den Rhythmus der Zeit einfangen: Erzählexperimente in der Deutschschweizer Gegenwartsliteratur unter besonderer Berücksichtigung der Werke von Otto F. Walter, Gerold Späth und Zsuzsanna Gahse. Würzburg: Königshausen \& Neumann, 2008.

\section{Niemieckojęzyczna literatura Szwajcarii bez tabu}

Abstrakt: W artykule recenzyjnym przedstawiono i omówiono tom Tabuzonen und Tabubrüche in der Deutschschweizer Literatur, opublikowany w 2020 roku w wydawnictwie Vandenhoeck \& Ruprecht, ze wsparciem finansowym Jan Michalski Fondation i Uniwersytetu Szcze- 
cińskiego, pod redakcją Doroty Sośnickiej, poświęcony współczesnym fenomenom literatury szwajcarskiej, literackim obrazom tabuizacji i prób przełamywania tabu. Krótkie krytyczne odniesienia do zamieszczonych w tomie tekstów pozwalają na rozpoznanie kluczowych zagadnień i towarzyszących im kontekstów, będąc w założeniu wskazówką do lektury całego, niezwykle interesującego projektu.

Słowa kluczowe: literatura współczesna, niemieckojęzyczna literatura Szwajcarii, tabu w literaturze, przełamywanie tabu.

\title{
Deutschsprachige Literatur der Schweiz ohne Tabu
}

\begin{abstract}
Der Übersichtsartikel präsentiert und diskutiert den 2020 vom Verlag Vandenhoeck \& Ruprecht mit finanzieller Unterstützung der Jan Michalski Fondation und der Universität Szczecin von Dorota Sośnicka herausgegebenen Band Tabuzonen und Tabubrüche in der Deutschschweizer Literatur, der sich den zeitgenössischen Phänomenen der Schweizer Literatur, literarischen Tabubildern und Versuchen, Tabus zu brechen, widmet. Kurze kritische Verweise auf die im Band enthaltenen Texte ermöglichen die Identifizierung von Schlüsselthemen und den damit verbundenen Kontexten und sollen als Leitfaden für die Lektüre des gesamten, äußerst interessanten Projekts dienen.

Schlüsselwörter: Gegenwartsliteratur, deutschsprachige Literatur der Schweiz, Tabu in der Literatur, Tabubrüche.
\end{abstract}

